

\title{
LOS ALAMOS NATIONAL LABORATORY (LANL) DESIGN CRITERIA FOR PFP STABILIZATION OF POLYCUBES, PROJECT C-227
}

\author{
HR Risenmay \\ B\&W Hanford Company \\ Post Office Box 1200 \\ Richland, WA 99352 \\ U.S. Department of Energy Contract DE-AC06-96RL13200

$\begin{array}{ll}\text { EDT/ECN: } 612499 & \text { UC: } \\ \text { Org Code: } 15500 & \text { Charge Code: } 100767 \\ \text { B\&R Code: } & \text { Total Pages: } 21\end{array}$

Key Words: Stabilization, PFP, Polycubes

Abstract: This document provides the design criteria for the Los Alamos National Laboratory design of a thermal stabilization process for polycubes stored at PFP.

Hastelly is a trademark of stellite Rod Division Stoody Deloro stellite, Inc., Industry $\mathrm{CA}$.

Honeywell is a registered trademark of Honeywell Inc., Minneapolis, MN.

TRADEMARK DISCLAIMER. Reference herein to any specific commercial product, process, or service by trade name, trademark, manufacturer, or otherwise, does not necessarily constitute or imply its endorsement, recommendation, or favoring by the United States Government or any agency thereof or its contractors or subcontractors.

Printed in the United States of America. To obtain copies of this document, contact: Document Control Services, P.O. Box 950, Mailstop H6-08, Richland WA 99352, Phone (509) 372-2420; Fax (509) 376-4989.
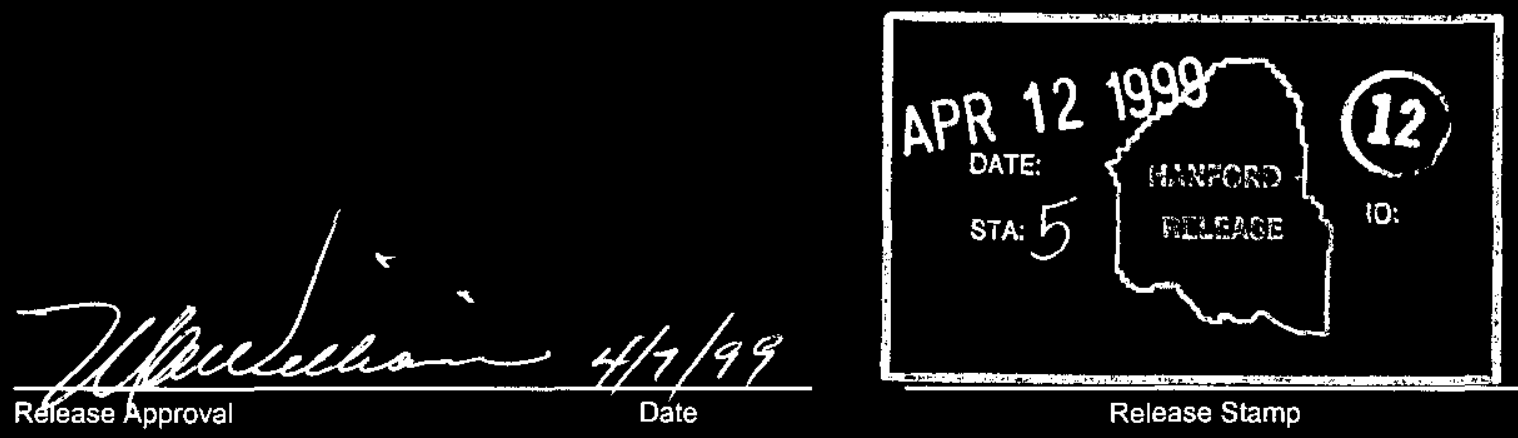

Release Stamp

\section{Approved For Public Release}


LIST OF ACRONYMS, ABBREVIATIONS AND DEFINITIONS................................. 2

$1.0 \quad$ INTRODUCTION ............................................................................... 4

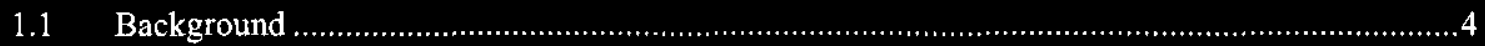

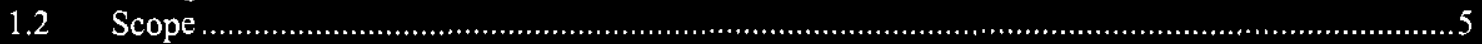

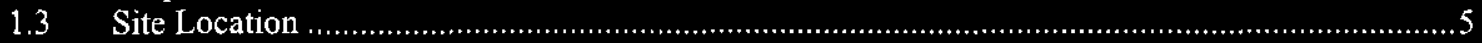

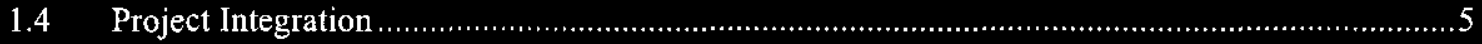

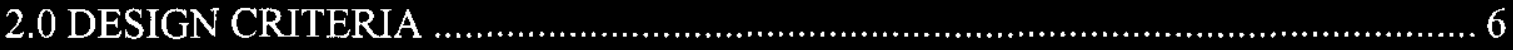

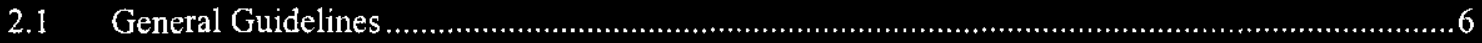

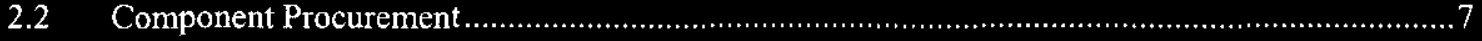

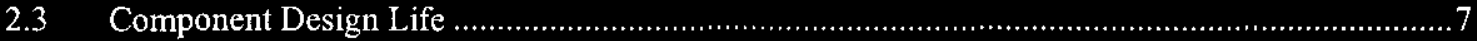

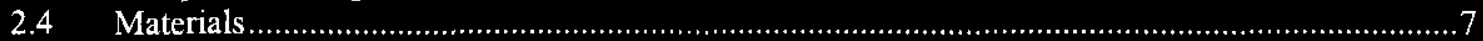

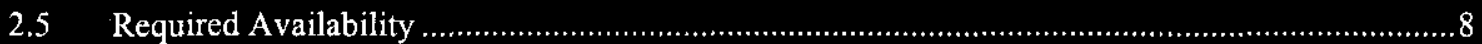

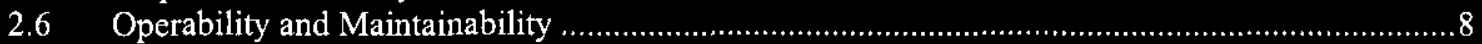

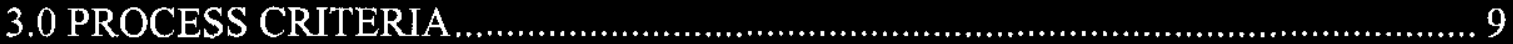

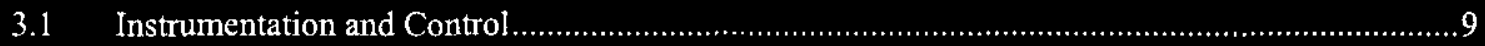

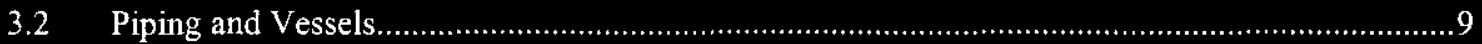

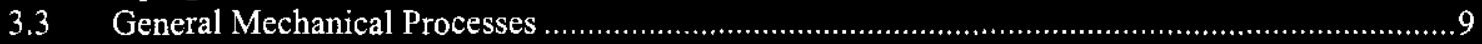

4.0 FACILITY CRITERIA ....................................................................... 10

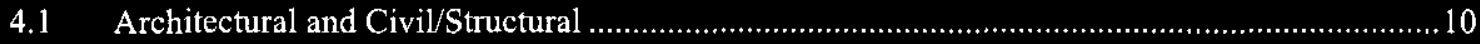

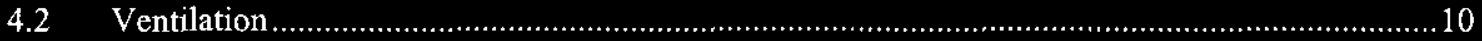

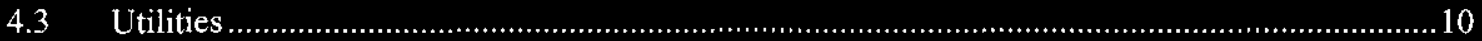

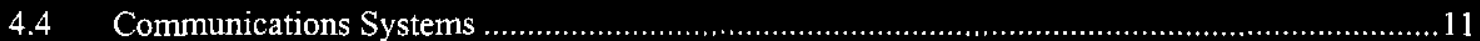

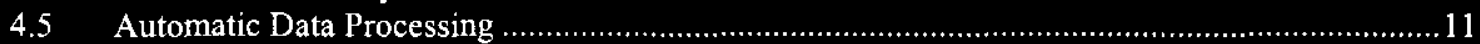

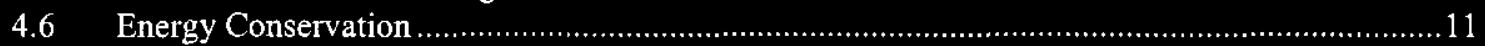

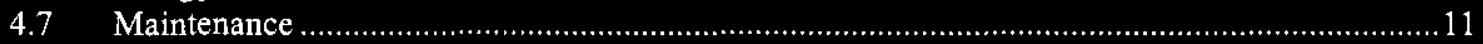

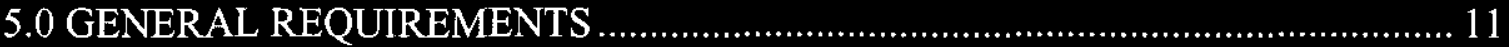

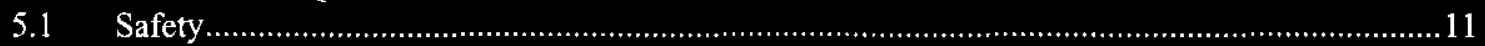

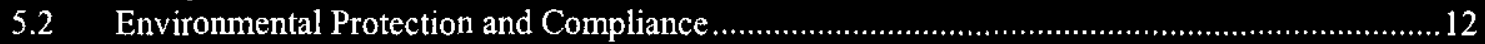

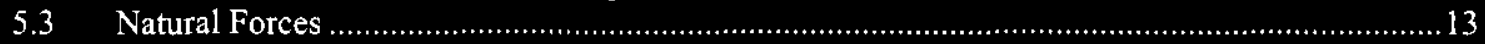

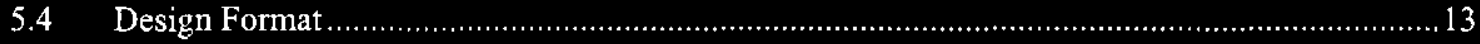

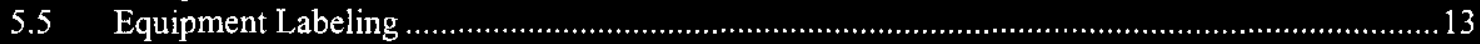

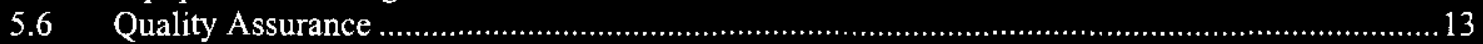

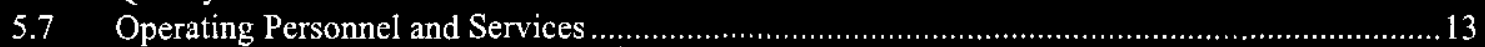

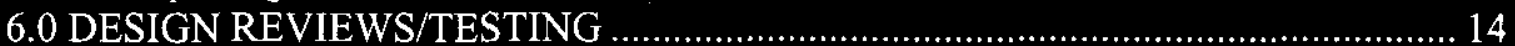

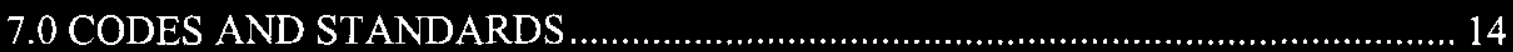

7.2 U.S. Code of Federal Regulations and State Laws ........................................................... 15

7.3 U.S. Department of Energy - Headquarters ..................................................................... 15

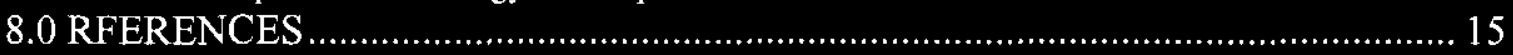

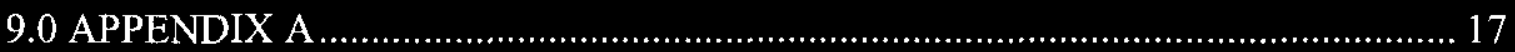

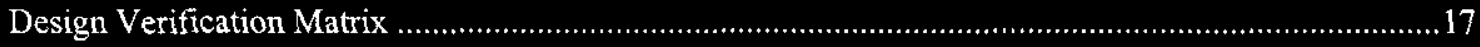




\section{LIST OF ACRONYMS, ABBREVIATIONS AND DEFINITIONS}

\begin{tabular}{ll} 
ALARA & As Low as Reasonably Achievable \\
ATP & Acceptance Test Procedure \\
BWHC & B\&W Hanford Company \\
C & Celsius \\
CSER & Criticality Safety Evaluation Report \\
DBE & Design Basis Earthquake \\
DNFSB & Defense Nuclear Facilities Safety Board \\
DOE & United States Department of Energy \\
DRE & Destructive Removal Efficiency \\
EIS & Environmental Impact Statement \\
FDH & Fluor Daniel Hanford, Inc. \\
FDNW & Fluor Daniel Northwest, Inc. \\
FSAR & Final Safety Analysis Report \\
HA & Hazard Analysis \\
HEPA & High Efficiency Particulate Air \\
LAN & Local Area Network \\
LANL & Los Alamos National Laboratory \\
LOI & Loss-on-Ignition \\
NOC & Notice of Construction \\
OSR & Operational Safety Requirement \\
OTP & Operability Test Procedure \\
OTR & Operability Test Report \\
PAX & Private Automatic Exchange \\
PFP & Plutonium Finishing Plant \\
PLC & Programmable Logic Controller \\
PNNL & Pacific Northwest National Laboratory \\
PPE & Personal Protective Equipment \\
Pu & Plutonium \\
PVMP & Plutonium Vulnerability Management Plan \\
QAPP & Quality Assurance Program Plan \\
R & Roentgen \\
RMC & Remote Mechanical C Line \\
ROD & Record of Decision \\
SDP & Silent Discharge Plasma \\
SESC & SGN Eurisys Services Corporation \\
SISMP & Site Integrated Stabilization Management Plan \\
THC & Total Hydrocarbon Monitor \\
U & Uranium \\
UBC & Uniform Building Code \\
VOC & Volatile Organic Carbon \\
WHC & Westinghouse Hanford Company \\
wt $\%$ & weight percent \\
& \\
\hline
\end{tabular}

Fine - Particles that have an aerodynamic diameter of less that 10 microns (micrometers). 
HNF-4070, Rev. 0

Process - To extract, separate, purify, stabilize or fabricate a material by physical, chemical, or mechanical means.

Residue - Process-generated plutonium-bearing materials not classified as storable metal or stabilized oxide that contain a non-discardable quantity of plutonium. 
HNF-4070, Rev. 0

\section{PFP STABILIZATION OF POLYCUBES}

\subsection{INTRODUCTION}

\subsection{Background}

This project addresses the stabilization of polycubes which is a class of residues and oxides with $<50$ weight percent $(\mathrm{wt} \%)$ Plutonium $(\mathrm{Pu})$. Currently there are 251 cans of polycubes at the Plutonium Finishing Plant (PFP).

The baseline plan is to utilize a pyrolysis process to stabilize the polycubes prior to packaging for storage, in accordance with the Record of Decision (ROD), issued June 25, 1996, for the Plutonium Finishing Plant Stabilization Final Environmental Impact Statement DOE/EIS-0244-F.

The polycubes were manufactured at Hanford in the 1960s for the purpose of criticality studies. They are a mixture of plutonium and/or uranium oxide and a polystyrene (Vinyl Benzene) typically $1 / 2$ " x 2" x 2" up to 2" x 2" x2". The cubes were sealed with a coating of aluminum paint and/or tape. The cubes were packaged in vented food cans with five to eight cubes per can. There are estimated to be 1600 polycubes stored at the PFP. Some polycube containers are suspected to contain loose material left over from the forming process and radiolysis.

Polycubes have a fairly high ${ }^{240} \mathrm{Pu}$ content and present a challenge for handling, due to the seven to eight Rem contact dose rate. Significant hazards associated with unstabilized polycubes arise from the polystyrene matrix, which generates hydrogen gas due to radiolysis. In addition, some cans of polycubes may contain fines. A hazard analysis for the polycube process has not been completed.

Due to their composition, the polycubes require a stabilization process that decomposes and separates the polystyrene from the plutonium oxide before thermal processing. The polycubes will first be treated in a pyrolysis furnace to decompose and vaporize the polystyrene. The material may be transported to one of the existing muffle furnaces, to oxidize the residual carbon, and stabilize the residual plutonium oxide.

For this project, Los Alamos National Laboratory (LANL) performed tests which identified a pyrolysis furnace adequate for stabilization of the polycubes stored at PFP and identified a suitable off-gas treatment method. Results of these tests documented in the Stabilization of Polycubes Engineering Study, WHC-SD-CP-I204, concluded that pyrolysis along with Silent Discharge Plasma (SDP) off-gas treatment is the recommended method of stabilization. Subsequent to this, a catalytic unit was deemed more appropriate and recommended by LANL during a June 1998 meeting at Hanford. 
HNF-4070, Rev. 0

\subsection{Scope}

The scope of this specification is to include design aspects for the process equipment, peripheral equipment and documents to be provided by LANL to be provided for the remediation of the 251 cans of polycubes currently in inventory at the PFP.

The finished product form for the stabilized polycubes will be plutonium oxide fired to meet the minimum temperature $\left(950^{\circ} \mathrm{C}\right.$ for at least two hours) necessary to meet the DOE standard, DOE-STD-3013-96, for 50-year storage.

Additional design requirements will be provided as necessary to identify other requirements not included in this scope, but required to fully scope the project.

\subsection{Site Location}

The pyrolysis stabilization system will be located at the Plutonium Finishing Plant (PFP) on the Hanford Site. The location at PFP is in glovebox HC-15. All locations assume that the controls and instrumentation will be installed in an exterior location away from radiation areas. Once loaded with product, the pyrolysis process will be controlled from this location.

\subsection{Project Integration}

1.4.1 The polycube process design effort will be shared between LANL and BWHC. It will be LANL's responsibility to design the basic processing equipment. It will be BWHC's responsibility to provide the locations, utilities, and installation of the unit at Hanford. BWHC will provide the basic design criteria, determine the location of the unit, and to work with LANL in defining ALARA requirements for the unit.

1.4.2 The system shall be designed such that all controls will be mounted external to the system.

1.4.3 Instruments mounted on the equipment must be legible from a distance of eight feet or at the instrument readouts on the control room panel..

1.4.4 Personnel required to operate the pyrolysis stabilization process/equipment will not require additional restrooms, change rooms, lockers, etc. No personnel services are provided by this project.

1.4.5 Fire detection and suppression requirements will not be included in this specification, but will be provided by the operating facility. 
HNF-4070, Rev. 0

\subsection{DESIGN CRITERIA}

\subsection{General Guidelines}

2.1.1 Plutonium-bearing polycubes will be processed in a stabilization system designed to produce non-reactive plutonium oxide in preparation for dry storage. The system design must include all unusual and customary components of the design, engineering and construction aspects of this specification. Specific deliverables include:

2.1.1.1 Engineering drawings (five copies, CAD dataset in Auto desk Auto CAD format

2.1.1.2 Vendor information

2.1.1.3 Design studies and calculations

2.1.1.4 Spare parts recommendations

2.1.1.5 Hazards analysis support

2.1.1.6 Process flow diagrams

2.1.1.7 Process material balances

2.1.1.8 Process energy balances and steam temperatures

2.1.1.9 Process control scheme.

2.1.1.10 Two pyrolysis systems will be provided by LANL

2.1.1.11 A nominal 10-hour cycle time will be established for the operation of the process system

2.1.2 Fit into glovebox HC-15 (preferably sealed in through a 21" seal-in port).

2.1.3 Minimize the potential for a release of volatized styrene into the glovebox by using a sealed system.

2.1.4 The surface temperature of exposed components shall not exceed $400^{\circ} \mathrm{C}$. Elements exceeding a surface temperature of $140^{\circ} \mathrm{F}$ shall be guarded to prevent inadvertent contact.

2.1.5 Require minimal feed preparation.

2.1.6 Be designed geometrically favorable from a criticality standpoint. 
2.1.7 Minimize secondary waste, both in hazard and quantity.

2.1.8 Remove $99 \%$ of the organics during the off-gas treatment.

2.1.9 Meet the environmental estimates of the Environmental Impact Statement (Reference 7.3.2).

2.1.10 Be self shielding (or remotely operated) to minimize exposure.

2.1.11 Use Honeywell model 9000 PLC system supplied by PFP. Software programming will be performed by PFP personnel.

2.1.12 Each system shall be designed for a nominal process rate of 2-4 2"x2"x2" polycubes per 24-hour day. The total quantity of polystyrene per unit cycle will not exceed 134 grams. The resulting product will be used as feed material for Thermal Stabilization Process to meet DOESTD-3013-96 specifications.

\subsection{Component Procurement}

2.2.1 Long lead items that are likely to be safety class equipment should be bid by LANL as level 1 procurements unless agreement has been obtained from BWHC.

\subsection{Component Design Life}

2.3.1 Components subject to thermal stresses during processing shall have a design goal of a six-month operating life span. But since the design life cannot be demonstrated, a test program agreed to by LANL and BWHC will be developed to test the components through some level of cycling prior to shipment to Hanford.

\subsubsection{Other component life spans will be estimated}

\subsection{Materials}

2.4.1 Materials of construction shall be suitable for intended service and resistant to radiation and corrosive off gases (chlorides) as appropriate.

2.4.2 Materials other than the furnace which are exposed to high temperatures $\left(300^{\circ} \mathrm{C}\right.$ to $\left.700^{\circ} \mathrm{C}\right)$ shall be fabricated from a 300 series stainless steel, or a similar stainless steel with high temperature properties.

2.4.3 The pyrolysis furnace chamber lid and other components shall be constructed from Hastelloy-X or equivalent to withstand the high temperatures $\left(700^{\circ}\right.$ to $\left.800^{\circ} \mathrm{C}\right)$, and the corrosive environment. 
2.4.4 The catalytic converter shall be constructed of Hastelloy-X or equivalent to withstand the corrosive off-gasses.

\subsection{Required Availability}

2.5.1 The pyrolysis stabilization system shall be designed for batch operation. Furnace(s) shall be operated five days per week, 24 hours per day.

2.5.2 The system should be designed to have an operational availability not less than $80 \%$ of scheduled operations, and require minimal maintenance. The intent of this item is to design the system to be easily repaired, have redundant systems, or overdesign of critical components, in order to reduce unscheduled downtime.

\subsection{Operability and Maintainability}

2.6.1 Human factors engineering shall be considered throughout the design of the stabilization system. For example, preference shall be given toward sealing mechanisms that a trained operator can handle without special tools.

2.6.2 Instrumentation and controls shall have the capability of monitoring and controlling all parameters necessary for operations.

2.6.3 Equipment shall be spaced to allow access for service and operational needs.

2.6.4 The pyrolysis system must be capable of being operated and maintained with standard glovebox handling devices.

2.6.5 The design shall include all fixtures and devices for remote handling and operating of the unit. This does not include items such as hoists or manipulators, which shall be supplied by the operating facilities.

2.6.6 Specific items that must be designed for remote handling include:

2.6.6.1 Furnace insert.

2.6.7 Locations on the system that are prone to plugging after steady and prolonged use shall be identified.

2.6.8 The design will enable easy replacement of maintenance items.

2.6.9 The system shall be of modular design. 
HNF-4070, Rev. 0

\subsection{PROCESS CRITERIA}

\subsection{Instrumentation and Control}

3.1.1 All instrumentation and controls necessary to monitor and control operation of the stabilization system shall be installed in a separate panel designed for operation in radiologically clean environment. Sensors may be mounted on the equipment as needed if designed for the glovebox environment.

3.1.2 The software utilized by the controller for the operation of the pyrolysis furnaces and off-gas treatment operations shall be developed, acquired and used in accordance with HNF-PRO-309, Computer Software Quality Assurance Requirements, and HNF-PRO-310, Computer Security Within the Procurement Cycle.

3.1.3 The capability for automatic data logging of all process variables shall be included.

\subsection{Piping and Vessels}

3.2.1 Piping and tubing will be stainless steel or Hastelloy-X material and PFA tubing as required.

3.2.2 Vessels will be of corrosion resistant materials such as stainless steel, Hastelloy-X, or Hastelloy-B-2.

\subsection{General Mechanical Processes}

\subsubsection{Conversion Processing System}

3.3.1.1 The furnaces shall be controlled with a control system provided by LANL.

\subsubsection{Off-gas Treatment System}

3.3.3.1 The pyrolysis off-gas shall be treated with an off-gas treatment system. The off-gas treatment system shall handle a peak gas generation rate of $5 \mathrm{~g} / \mathrm{min}$. styrene per cycle. This is capable of handling a polystyrene loading of 134 grams per batch in a single unit.

3.3.3.2 Total Hydrocarbon (THC) and $\mathrm{CO}_{2}$ monitors shall be located in the discharge line. 
3.3.3.3 The off gas system shall have a minimum destructive removal efficiency (DRE) of $99 \%$.

3.3.3.4 The system will target DRE of $99.9 \%$ removal.

\subsection{FACILITY CRITERIA}

\subsection{Architectural and Civil/Structural}

4.1.1 The design and construction of the system shall be in accordance with the Uniform Building Code (UBC), DOE seismic design requirements and other regulations, orders, directives. Codes, and standards as listed in Sections 7 and 8 .

\subsection{Ventilation}

4.2.1 The pyrolysis stabilization system should exhaust to a piping system that may be mated to the facility ventilation system or vented to the glovebox.

4.2.2 Final flow rate and exhaust configuration will be based on LANL test results.

\subsection{Utilities}

4.3.1 Utility support services to be provided.

\subsubsection{Argon.}

\subsubsection{Instrument/process air.}

4.3.1.3 All the utility support services above only entail piping connections to existing plant headers.

\subsubsection{Cooling water as needed.}

\subsubsection{Electrical}

4.3.2.1 Available power for the stabilization unit and its related equipment shall be rated for 2500 watts and 240 volt single phase volt power, supplied from building power panels located in the project area.

4.3.2.2 The electrical design shall be in compliance with the current edition of the National Fire Protection Code (NFPA 70). 
HNF-4070, Rev. 0

\subsubsection{Lighting}

4.3.3.1 General lighting for the stabilization unit installation and operation will be provided by the existing building lighting system.

\subsection{Communications Systems}

4.4.1 No additional communications equipment will be installed.

\subsection{Automatic Data Processing}

4.5.1 No additional automatic data processing is required other than that described in Section 3.

\subsection{Energy Conservation}

\subsubsection{N/A}

\subsection{Maintenance}

4.7.1 The stabilization system will be designed to permit routine maintenance activities utilizing remote handling devices.

4.7.2 The system shall minimize exposure to hazardous or radioactive environments.

4.7.3 Short lived components such as instruments, heating elements, catalytic converter catalyst, etc., shall be designed for ease of maintenance.

\subsection{Decommissioning}

4.8.1 The system design shall consider the decommissioning effort, and include provisions to limit the hazards to environment and personnel, and to minimize the expense.

\subsection{GENERAL REQUIREMENTS}

\subsection{Safety}

\subsubsection{Criticality}

5.1.1.1 All equipment, vessels, and piping shall be geometrically favorable to prevent criticality.

5.1.1.2 Program/project designs shall conform to the requirements listed in HNF-PRO-537, Criticality Safety Control of Fissionable Material. 
HNF-4070, Rev. 0

\subsubsection{Safety Analysis}

5.1.2.1 LANL will support a Hazards Analysis preparation. The design' will reflect all controls and interlocks identified as required by this analysis.

\subsubsection{Shielding}

5.1.3.1 Shielding shall be provided where appropriate, to reduce personnel radiation exposure levels to ALARA in accordance with the requirements of 10 CFR 835, "Occupational Radiation Protection" DOE/EV/1830.T5, "A Guide to Reducing Radiation Exposure to As Low as Reasonably Achievable (ALARA) and HNF-PRO-1622 "Radiological Design Review Process."

5.1.3.2 Shielding installation shall be in accordance with the Uniform Building Code (UBC).

\subsubsection{Industrial Safety}

5.1.4.1 All high voltage sources shall be protected from routine access.

5.1.4.2 The design and construction shall assure compliance with applicable industrial health and safety standards (29 CFRs 1910 and 1926).

\subsubsection{Industrial Hygiene}

5.1.5.1 The design and construction shall assure compliance with applicable industrial health and safety standards (29 CFRs 1910 and 1926), and the most recent consensus standards applicable to occupational safety and health (e.g. ACGIH Threshold Limit Values for Chemical Substances and Physical Agents and Biological Exposure Indices).

\subsubsection{Fire Protection}

5.1.6.1 Design shall comply with the fire protection requirements of HNFPRO-349, Fire Protection Design Criteria..

\subsection{Environmental Protection and Compliance}

5.2.1 Not applicable. 
HNF-4070, Rev. 0

\subsection{Natural Forces}

5.3.1 Natural phenomena events will be a consideration in the hazard analysis. LANL will provide assistance to BWHC in assessing natural phenomena related safety risks as a part of their safety analysis considerations. (See Section 5.1.2.1)

\subsection{Design Format}

5.4.1 Drawings that interface with existing PFP facility drawings shall provide traceability to these existing drawings by identifying the affected drawings in accordance with HNF-PRO-1819, PHMC Engineering Requirements.

5.4.2 Equipment Component Identifier numbers designated for new equipment shall be defined in accordance with WHC-SD-CP-RD-024, Component Identifying Standard for the PFP.

\subsection{Equipment Labeling}

5.5.1 Equipment component labeling will be completed in accordance with WHC-CM-5-8, Section 1.19, "Plutonium Finishing Plant Administration."

\subsection{Quality Assurance}

5.6.1 Quality Assurance and Quality Control services shall be provided for design specification, design media, materials procurement, fabrication, installation and acceptance testing activities. Requirements imposed by and derived from 10 CFR 830.120 shall be implemented using a graded approach to assure that customer requirements are met and that the final installation will perform as the designers intended.

5.6.2 All work performed on site and off site shall be performed in accordance with an approved Quality Assurance Program Plan (QAPP), which shall implement 10 CFR 830.120 . The QAPP of LANL shall be approved by BWHC.

\subsection{Operating Personnel and Services}

5.7.1 All valves should be positioned such that the valve can be seen during manipulation from the same side of the equipment.

5.7.2 All equipment must be accessible from glove ports to allow for maintenance.

\subsection{Training}




\subsection{DESIGN REVIEWS/TESTING}

6.1 A design review shall be conducted at the $90 \%$ completion level of the design process with the participation of BWHC personnel.

6.2 A design review shall conform to LANL procedure ATP/SRL-101, Design Interface and Control, and shall include the following:

\subsubsection{Human factors}

\subsubsection{Maintainability}

\subsubsection{Operability}

6.2.4 Environmental compliance

\subsubsection{Design criteria compliance}

\subsubsection{Safety}

6.2.7 ALARA and radiological control compliance

\subsubsection{Constructability}

6.3 Operability testing shall be conducted at LANL to ensure that the units meet the performance requirement of the design criteria. The results of the operability test shall be reviewed and approved by BWHC prior to shipping the unit to Hanford.

\subsection{CODES AND STANDARDS}

7.1 The design and construction of the stabilization system shall comply with the current versions of the codes and standards of the following organizations:

7.1.1 American Conference of Government Industrial Hygienists (ACGIH).

7.1.2 American Society of Mechanical Engineers (ASME).

7.1.3 Environmental Protection Agency (EPA).

7.1.4 Institute of Electrical and Electronics Engineers (IEEE).

7.1.5 Instrument Society of America (ISA).

7.1.6 National Electrical Code (NFPA 70).

7.1.7 Uniform Building Code (UBC). 
HNF-4070, Rev. 0

7.1.8 American Society for Testing and Materials (ASTM)

\subsection{U.S. Code of Federal Regulations and State Laws}

7.2.1 10 CFR 830.120, "Nuclear Safety Management Quality Assurance."

7.2.2 10 CFR 835, "Occupational Radiation Protection"

7.2.3 10 CFR 1910, "Occupational Safety and Health Standards."

7.2.4 National Environmental Policy Act (NEPA).

7.2.5 National Emissions Standards and Hazardous Air Pollutants (NESHAP).

7.2.6 Resource Conservation and Recovery Act (RCRA).

\subsection{U.S. Department of Energy - Headquarters}

7.3.1 Department of Energy DOE-STD-3013-96, Criteria for Preparing and Packaging Plutonium Metals and Oxides for Long-Term Storage.

7.3.2 Department of Energy DOE/EI-0244-F, Plutonium Finishing Plant Stabilization Final Environmental Impact Statement.

7.3.3 Department of Energy DOE/EV/1830.T5, A Guide to Reducing Radiation Exposure to As Low As Reasonably Achievable (ALARA).

7.3.4 Department of Energy Order 5480.28, National Phenomena Hazards Mitigation.

7.3.5 "Record of Decision for Plutonium Finishing Plant Stabilization Final Environmental Impact Statement, Hanford Site, Richland, Washington Federal Register," Volume, 61, No. 133, pp 36352-36359.

\subsection{RFERENCES}

8.1 HNF-MP-599, Quality Assurance Program Description

8.2 HNF-PRO-539, Criticality Safety Evaluations

8.3 HNF-PRO-704, Hazard and Accident Analysis Process

8.4 HNF-PRO-1819, PHMC Engineering Requirements

8.5 WHC-SD-CP-RD-024, Component Identifying Standard for the PFP

Page 15 of 20 
HNF-4070, Rev. 0

8.6 WHC-SD-CP-SAR-021, PFP Final Safety Analysis Report

8.7 WHC-SD-CP-TI-204, Stabilization of Polycubes Engineering Study

8.8 HNF-PRO-1622, Radiological Design Review Process

8.9 HNF-PRO-1633, ALARA Program Records

Page 16 of 20 
HNF-4070, Rev. 0

\subsection{APPENDIX A}

\section{Design Verification Matrix}

\begin{tabular}{|c|c|c|c|c|c|c|}
\hline $\begin{array}{l}\text { Sect. } \\
\text { No. }\end{array}$ & Requirement Title & $\begin{array}{c}\text { Rqmt } \\
\text { ID }\end{array}$ & Review & Analysis & Demo. & Test \\
\hline 2.1 .1 & Design deliverables & & $\mathrm{X}$ & & & \\
\hline 2.1 .2 & Fit into glovebox HC-15 & & & $\mathrm{X}$ & & \\
\hline 2.1 .3 & $\begin{array}{l}\text { Minimize release of volatized } \\
\text { styrene }\end{array}$ & & $\mathrm{X}$ & & & \\
\hline 2.1 .4 & $\begin{array}{l}\text { Surface temperature not to } \\
\text { exceed } 350^{\circ} \mathrm{C}\end{array}$ & & & & & $\mathrm{X}$ \\
\hline 2.1 .5 & Minimum feed preparation & & $\mathrm{X}$ & & & \\
\hline 2.1 .6 & Geometrically safe & & & & $\mathrm{X}$ & \\
\hline 2.1 .7 & Minimum waste & & $\mathrm{X}$ & & & \\
\hline 2.1 .8 & $\begin{array}{l}\text { Remove } 99 \% \text { of organics (tested } \\
\text { at Hanford) }\end{array}$ & & & & & $\mathrm{X}$ \\
\hline 2.1 .9 & $\begin{array}{l}\text { Meet EIS environmental } \\
\text { estimates }\end{array}$ & & & & & $\mathrm{X}$ \\
\hline 2.1 .10 & $\begin{array}{l}\text { Be self shielding to minimize } \\
\text { exposure }\end{array}$ & & & $\mathrm{X}$ & & \\
\hline 2.1 .11 & $\begin{array}{l}\text { Use Honeywell PLC control } \\
\text { system }\end{array}$ & & $\mathrm{X}$ & & & \\
\hline 2.1 .1 .2 & $\begin{array}{l}\text { System design for } 12 \text { polycubes } \\
\text { each day }\end{array}$ & & & $\bar{X}$ & & \\
\hline 2.3 .1 & Six month life span & & & & $\mathrm{X}$ & \\
\hline 2.3 .2 & Life span to be estimated & & $\mathrm{X}$ & & & \\
\hline 2.4 .1 & Materials suitable for use & & $\mathrm{X}$ & & & \\
\hline 2.4 .2 & Use 300 stainless steel & & $\mathrm{X}$ & & & \\
\hline 2.4 .3 & Use Hastelloy-X over $700^{\circ} \mathrm{C}$ & & $\mathrm{X}$ & & & \\
\hline 2.4 .4 & $\begin{array}{l}\text { Catalytic converter to be } \\
\text { Hastelloy-X }\end{array}$ & & $\mathrm{X}$ & & & \\
\hline 2.5 .1 & Designed for $50 /$ week operation & N/A & & & & \\
\hline 2.5 .2 & $\begin{array}{l}\text { Operational availability to be } \\
80 \%\end{array}$ & & $\mathrm{X}$ & & & \\
\hline 2.6 .1 & Human factors to be considered & & $\mathrm{X}$ & & & \\
\hline 2.6 .2 & $\begin{array}{l}\text { Instrumentation and controls } \\
\text { shall monitor all required } \\
\text { parameters }\end{array}$ & & & & & $\mathrm{X}$ \\
\hline 2.6 .3 & Equipment spaced for access & & & & & $\mathrm{X}$ \\
\hline 2.6 .4 & $\begin{array}{l}\text { Standard components shall be } \\
\text { used }\end{array}$ & & $\mathrm{X}$ & & & \\
\hline 2.6 .5 & $\begin{array}{l}\text { Must be capable of being } \\
\text { operated and maintained with } \\
\text { remote handlers }\end{array}$ & & & & $\bar{X}$ & \\
\hline
\end{tabular}


HNF-4070, Rev. 0

\begin{tabular}{|c|c|c|c|c|c|c|}
\hline $\begin{array}{l}\text { Sect. } \\
\text { No. }\end{array}$ & Requirement Title & $\begin{array}{c}\text { Rqmt } \\
\text { ID }\end{array}$ & Review & Analysis & Demo. & Test \\
\hline 2.6 .6 & $\begin{array}{l}\text { Design shall include all fixtures } \\
\text { for remote operations }\end{array}$ & & & & $\mathrm{X}$ & \\
\hline 2.6 .7 & $\begin{array}{l}\text { Remote handling equipment } \\
\text { included }\end{array}$ & & $\mathrm{X}$ & & & \\
\hline 2.6 .8 & Choke points to be identified & & $\mathrm{X}$ & & & \\
\hline 2.6 .9 & $\begin{array}{l}\text { Easy replacement of } \\
\text { maintenance items }\end{array}$ & & & & $\mathrm{X}$ & \\
\hline 2.6 .10 & $\begin{array}{l}\text { System shall be of modular } \\
\text { design }\end{array}$ & & $\mathrm{X}$ & & & \\
\hline 3.1 .1 & $\begin{array}{l}\text { All instrumentation and controls } \\
\text { shall be in a separate panel }\end{array}$ & & $\mathrm{X}$ & & & \\
\hline 3.1 .2 & $\begin{array}{l}\text { Software shall conform to HNF- } \\
\text { PRO-309 and } 310\end{array}$ & & $\mathrm{X}$ & & & \\
\hline 3.1 .3 & $\begin{array}{l}\text { Capability shall include } \\
\text { automatic data logging }\end{array}$ & & $\mathrm{X}$ & & & \\
\hline 3.2 .1 & $\begin{array}{l}\text { Piping and tubing shall be } \\
\text { stainless steel or Hastelloy-X }\end{array}$ & & $\mathrm{X}$ & & & \\
\hline 3.2 .2 & $\begin{array}{l}\text { Vessels will be of corrosion } \\
\text { resistant materials such as } \\
\text { stainless steel or Hastelloy-X }\end{array}$ & & $\mathrm{X}$ & & & \\
\hline 3.3 .1 .1 & $\begin{array}{l}\text { Furnaces shall be controlled with } \\
\text { a control system }\end{array}$ & & & & $\bar{X}$ & \\
\hline 3.3.3.1 & $\begin{array}{l}\text { Off gas system shall handle a } \\
\text { peak gas generation rate of } 5.0 \\
\mathrm{~g} / \mathrm{min} \text { styrene per system }\end{array}$ & & & & & $\mathrm{X}$ \\
\hline 3.3 .3 .2 & $\begin{array}{l}\text { A THC and } \mathrm{CO}_{2} \text { monitor shall be } \\
\text { located in the discharge line }\end{array}$ & & & & & $\begin{array}{c}\text { X } \\
\text { At } \\
\text { Hanford } \\
\end{array}$ \\
\hline 3.3 .3 .3 & $\begin{array}{l}\text { The DRE shall be a minimum of } \\
99 \%\end{array}$ & & & & & $\begin{array}{c}\mathrm{X} \\
\text { At } \\
\text { Hanford } \\
\end{array}$ \\
\hline 3.3 .3 .4 & The DRE shall target $99.9 \%$ & N/A & & & & \\
\hline 4.1 .1 & $\begin{array}{l}\text { Design and construction shall be } \\
\text { in accordance with the UBC }\end{array}$ & & $\mathrm{X}$ & & & \\
\hline 4.2 .1 & $\begin{array}{l}\text { The off gas system shall exhaust } \\
\text { into the facility ventilation } \\
\text { system }\end{array}$ & $\mathrm{N} / \mathrm{A}$ & & & & \\
\hline 4.2 .2 & $\begin{array}{l}\text { Final flow rate and exhaust } \\
\text { configuration will be based on } \\
\text { LANL tests } \\
\end{array}$ & N/A & & & & \\
\hline 4.2 .3 & $\begin{array}{l}\text { Glovebox supply air shall be } \\
\text { supplied by the local facility }\end{array}$ & N/A & & & & \\
\hline 4.3.1 & $\begin{array}{l}\text { Required utility support services } \\
\text { to be provided by local facility }\end{array}$ & N/A & & & & \\
\hline
\end{tabular}


HNF-4070, Rev. 0

\begin{tabular}{|c|c|c|c|c|c|c|}
\hline $\begin{array}{l}\text { Sect. } \\
\text { No. }\end{array}$ & Requirement Title & $\begin{array}{c}\text { Rqmt } \\
\text { ID }\end{array}$ & Review & Analysis & Demo. & Test \\
\hline 4.3 .2 .1 & $\begin{array}{l}\text { System shall utilize } 220 \text { and } 110 \\
\text { volt electrical power }\end{array}$ & & $\bar{X}$ & & & \\
\hline 4.3.2.2 & $\begin{array}{l}\text { Electrical design shall comply } \\
\text { with NFPA } 70\end{array}$ & & $\mathrm{X}$ & & & \\
\hline 4.3 .3 .1 & $\begin{array}{l}\text { General area lighting shall be } \\
\text { provided by the local facility }\end{array}$ & N/A & & & & \\
\hline 4.7 .1 & Routine maintenance by remote & & & & $\bar{x}$ & \\
\hline 4.7 .2 & Minimize exposure to hazards & & & $\mathrm{X}$ & & \\
\hline 4.7 .3 & $\begin{array}{l}\text { Short lived components designed } \\
\text { for maintenance }\end{array}$ & & & & $\mathrm{X}$ & \\
\hline 4.8 .1 & $\begin{array}{l}\text { D\&D requirements to be } \\
\text { considered }\end{array}$ & & $\mathrm{X}$ & & & \\
\hline 5.1 .1 .1 & $\begin{array}{l}\text { All equipment, vessels and } \\
\text { piping shall be geometrically } \\
\text { subcritical }\end{array}$ & & $\mathrm{X}$ & & & \\
\hline 5.1 .1 .2 & $\begin{array}{l}\text { Project designs shall conform to } \\
\text { HNF-PRO- } 537\end{array}$ & & $\mathrm{X}$ & & & \\
\hline 5.1 .2 .1 & Support hazards analysis & $\mathrm{N} / \mathrm{A}$ & & $\mathrm{X}$ & & \\
\hline 5.1 .3 .1 & $\begin{array}{l}\text { Shielding shall be provided to } \\
\text { reduce personnel radiation }\end{array}$ & & & $\mathrm{X}$ & & \\
\hline 5.1 .3 .2 & $\begin{array}{l}\text { Shielding shall be in accordance } \\
\text { with UBC }\end{array}$ & & $\mathrm{X}$ & & & \\
\hline 5.1 .4 .1 & $\begin{array}{l}\text { Electrical sources shall be } \\
\text { protected }\end{array}$ & & $\mathrm{X}$ & & & \\
\hline 5.1 .4 .2 & $\begin{array}{l}\text { Design to conform with } 29 \text { CFR } \\
1926\end{array}$ & & $\bar{X}$ & & & \\
\hline 5.1 .5 .1 & $\begin{array}{l}\text { Design shall comply with TLV } \\
\text { limits }\end{array}$ & & $\mathrm{X}$ & & & \\
\hline 5.1 .6 .1 & $\begin{array}{l}\text { Design to conform to HNF- } \\
\text { PRO-349 }\end{array}$ & & $\mathrm{X}$ & & & \\
\hline 5.3 .1 & $\begin{array}{l}\text { Natural phenomena events to be } \\
\text { considered }\end{array}$ & & $\mathrm{X}$ & & & \\
\hline 5.4 .1 & $\begin{array}{l}\text { Drawings shall comply with } \\
\text { HNF-PRO-1819 }\end{array}$ & & $\mathrm{X}$ & & & \\
\hline 5.4 .2 & $\begin{array}{l}\text { Equipment component identifier } \\
\text { numbers shall be in accordance } \\
\text { with WHC-SD-CP-RD-024 }\end{array}$ & & $\mathrm{X}$ & & & \\
\hline 5.5 .1 & $\begin{array}{l}\text { Equipment labeling shall } \\
\text { conform with WHC-CM-5-8, } \\
\text { Section } 1.19\end{array}$ & & $\mathrm{X}$ & & & \\
\hline 5.6 .1 & $\begin{array}{l}\text { Requirements of 10 CFR } \\
830.120\end{array}$ & & $\mathrm{X}$ & & & \\
\hline 5.6 .3 & Approved QAPP required & $\mathrm{N} / \mathrm{A}$ & & & & \\
\hline
\end{tabular}


HNF-4070, Rev. 0

\begin{tabular}{|c|l|c|c|c|c|c|}
\hline $\begin{array}{c}\text { Sect. } \\
\text { No. }\end{array}$ & \multicolumn{1}{|c|}{ Requirement Title } & $\begin{array}{c}\text { Rqm } \\
\text { ID }\end{array}$ & Review & Analysis & Demo. & Test \\
\hline 5.7 .1 & $\begin{array}{l}\text { Valves must operate from one } \\
\text { side }\end{array}$ & & & & $\mathrm{X}$ & \\
\hline 5.7 .2 & $\begin{array}{l}\text { All equipment must be } \\
\text { accessible from glove ports }\end{array}$ & & & & $\mathrm{X}$ & \\
\hline
\end{tabular}




\section{DISTRIBUTION SHEET}

To

Distribution

Project Title/Work Order

Los Alamos National Laboratory (LANL) Design Criteria for PFP

Stabilization of Polycubes, Project C-227

\begin{tabular}{l}
\hline \\
\hline J. E. Bramson \\
\hline R. A. Bond \\
\hline M. W. Gibson \\
\hline D. R. Groth \\
\hline M. R. Hahn \\
\hline R. Martinez \\
\hline S. E. Nunn \\
\hline H. R. Risenmay \\
\hline J. C. Sinclair \\
\hline M. E. Shaw \\
\hline J. E. Lacey \\
\hline Project Files - C-22? \\
\hline Central Files \\
\hline Doe.-Re Reading Room \\
\hline
\end{tabular}

From

PFP Project Management

(n)

\begin{tabular}{|l|c|l|c|c|} 
MSIN & $\begin{array}{c}\text { Text } \\
\text { With All } \\
\text { Attach. }\end{array}$ & Text Only & $\begin{array}{c}\text { Attach./ } \\
\text { Appendix } \\
\text { Only }\end{array}$ & $\begin{array}{c}\text { EDT/ECN } \\
\text { Only }\end{array}$ \\
\hline
\end{tabular}

Page 1 of 1

Date $03 / 11 / 99$

EDT No. 612499

ECN No. N/A 